\title{
Prevalence and risk factors for Cysticercus tenuicollis in goats and sheep in Paraíba, northeastern Brazil
}

Prevalência e fatores de risco para Cysticercus tenuicollis em caprinos e ovinos na Paraíba, Nordeste do Brasil

\author{
Dayana Firmino de Morais'; Vinícius Longo Ribeiro Vilela ${ }^{1,2 *}$; Thais Ferreira Feitosa ${ }^{2,3}$; \\ Vinícius Mamede dos Santos ${ }^{4}$; Vitória Régia Gouveia ${ }^{4}$; Ana Célia Rodrigues Athayde ${ }^{1,3}$; Sérgio Santos de Azevêdo ${ }^{2}$ \\ ${ }^{1}$ Programa de Pós-graduação em Zootecnia, Universidade Federal de Campina Grande - UFCG, Patos, PB, Brasil \\ ${ }^{2}$ Departamento de Medicina Veterinária, Instituto Federal da Paraíba - IFPB, Sousa, PB, Brasil \\ ${ }^{3}$ Programa de Pós-graduação em Medicina Veterinária, Universidade Federal de Campina Grande - UFCG, Patos, PB, Brasil \\ ${ }^{4}$ Unidade Acadêmica de Ciências Biológicas - UFCG, Patos, PB, Brasil
}

Received November 16, 2016

Accepted December 20, 2016

\begin{abstract}
This study aimed to determine the prevalence and risk factors for $C$. tenuicollis among goats and sheep in slaughterhouses in Paraíba. 390 animals (195 goats and 195 sheep) in the municipalities of Patos and Esperança, Paraíba, Brazil, were inspected between February and May 2014. The prevalence of C. tenuicollis was 39\% (76/195) in goats and 17.4\% $(34 / 195)$ in sheep. In both species, most of the cysticerci vesicles were located at the omentum and mesentery. The only risk factor found was extensive sheep farming. It can be concluded that $C$. tenuicollis is highly prevalent in small ruminants in Paraíba, being more prevalent in goats than in sheep. Extensively-reared sheep were twice as likely to develop infection by this parasite.
\end{abstract}

Keywords: Goat and sheep farming, cestode, Taenia hydatigena.

\section{Resumo}

Objetivou-se determinar a prevalência e os fatores de riscos de C. tenuicollis em caprinos e ovinos nos matadouros da Paraíba. Foram inspecionados 390 animais (195 caprinos e 195 ovinos) nos municípios de Patos e Esperança, Paraíba, Brasil, no período de Fevereiro a Maio de 2014. A prevalência de C. tenuicollis em caprinos foi de 39\% (76/195) e em ovinos de 17,4\% (34/195). Os locais mais acometidos por C. tenuicollis nas duas espécies foram o omento e o mesentério. $\mathrm{O}$ único fator de risco encontrado foi a produção extensiva de ovinos. Pode-se concluir que é alta a prevalência de C. tenuicollis em pequenos ruminantes no Estado da Paraíba, sendo mais prevalente na espécie caprina; e que ovinos criados de forma extensiva apresentam duas vezes mais riscos de contrais a infecção por este parasita.

Palavras-chave: Caprinovinocultura, cestódeo, Taenia hydatigena.

\section{Introduction}

The semi-arid region of northeastern Brazil has good potential for goat and sheep-rearing, with favorable environmental conditions and availability of different types of forage, given that most of these herds are raised extensively. Goat and sheep farming in Paraiba is accessible for producers, since the acquisition of animals can be funded through government programs (ANDRADE, 2007). There is high meat demand for trade, which is a source of income for small producers. However, despite the large population of small ruminants in northeastern Brazil, the production rates can be considered low for a variety of reasons, including the presence of parasitic diseases (AMARANTE, 2009).

${ }^{*}$ Corresponding author: Vinícius Longo Ribeiro Vilela. Instituto Federal da Paraíba - IFPB, Av. Presidente Tancredo Neves, s/n, Jardim Sorrilândia, CEP 58800-970, Sousa, PB, Brasil. e-mail: vilelavlr@yahoo.com.br
Cysticercus tenuicollis is a metacestode of Taenia hydatigena, for which the definitive hosts are dogs and wild canids. Its intermediate hosts are mainly goats, sheep, pigs, cattle, horses and deer. The adult form T. hydatigena releases eggs into the feces of definitive hosts, thus facilitating intake by ruminant animals while grazing. Once ingested, the eggs hatch in the small intestine and start to migrate to other visceral organs. This may cause appetite loss, weight loss and, hence, reduction of meat and milk production (ORYAN et al., 2012).

Infection with $C$. tenuicollis favors infection and growth of pathogenic microorganisms that can cause necrotic hepatitis, which gives rise to economic losses associated with reduced productivity among the affected animals and condemnation of damaged organs (POPOVA \& KANCHEV, 2013). In high 
infections, mortality may occurs, as described by Scala et al. (2016) in central Sardinia, Italy, where an acute outbreak of T. hydatigena cysticercosis occurred, causing mortality in 5 of 21 (23.8\%) female lambs. In Greek slaughtered sheep, the infection level due to C. tenuicollis was $29.4 \%$ (CHRISTODOULOPOULOS et al., 2008). The infection levels in small ruminant carcasses in Brazil are high. In Ceará, Brazil, the rate was 32\% (SOARES et al., 2012). The State of Paraíba, Brazil, has 167,477 farms that account for a total of 566.576 goats and 501.362 sheep (IBGE, 2006, 2015). In Paraíba, there are no studies reporting the infection levels due to $C$. tenuicollis in small ruminants.

According to Kouam et al. (2014), research directed towards the risk factors that lead to development of a given disease or pathogen are of the utmost importance, since this has the aims of helping to formulate control strategies. Therefore, the aim of the present study was to determine the prevalence and the identification of some putative risk factors for $C$. tenuicollis in goats and sheep from the municipal slaughterhouses of the municipalities of Patos and Esperança, Paraíba, Brazil.

\section{Materials and Methods}

This study was conducted in two public municipal slaughterhouses of the municipalities of Patos and Esperança, which are located in Sertão and Agreste mesoregions of Paraíba, respectively. These slaughterhouses were selected because they are authorized by the municipal inspection service to slaughter up to 15 small ruminants per day.

The study was carried out from February to May 2014. Samples were collected during 10 visits to each slaughterhouse. A thorough inspection of the abdominal cavity was performed to determine the preferential location of cysticerci vesicles. Inspection was directed towards the omentum, liver, gallbladder and other abdominal organs. All animals slaughtered in the visit day were inspected. In total, 390 animals (195 goats and 195 sheep) were evaluated for the presence of $C$. tenuicollis.

The samples were analyzed in accordance with an observational study design. Sample analysis was done especially on the days on which it was possible to follow up the slaughter of small ruminants, with the possibility of analysis of carcasses and offal.

Immediately after each animal had been slaughtered, specimens of $C$. tenuicollis that were found were removed carefully with the aid of scissors and tweezers. They were then stored in properly identified plastic bags, and were transported in ice, in styrofoam boxes, to the Laboratory for Parasitic Diseases of Domestic Animals (LDPAD), of the Federal University of Campina Grande (UFCG), for macroscopic analysis followed by confirmation of the species.

In order to assess risk factors, a semi-structured questionnaire was applied individually to all the owners of the 390 slaughtered animals. The questionnaire was composed of five fields: two for identification of the farm and the animals; one regarding the management system [including the production system (intensive, extensive and semi-extensive), the number of animals in the farm and the existence of dogs in the farm]; another on the prevalence of $C$. tenuicollis in the farm; and the last field of the survey regarding the deworming practices, the total area of the farm and the flock size.

\section{Statistical analysis}

The number of samples analyzed was calculated taking into account a $50 \%$ expected prevalence of $C$. tenuicollis and a $95 \%$ confidence interval, assuming a statistical error of $10 \%$ (THRUSFIELD, 2007).

Possible associations between the presence of $C$. tenuicollis and the variables analyzed from the epidemiological questionnaire were ascertained using the chi-square test, in the BioEstat 5.0 software (AYRES et al., 2003).

\section{Ethics committee}

This study was approved by the Research Ethics Committee of UFCG under protocol number 178/2014 CEP.

\section{Results}

A total of 390 animals were evaluated in the two slaughterhouses. Goats inspected in the slaughterhouse of Patos came from 16 herds while those at Esperança originate from six herds. Sheep evaluated in the slaughterhouse of Patos originated from ten herds and those at Esperança were from seven herds. All the goats and sheep represented crossbreds.

The mean age at slaughter was two years (ranging from eigth months to four years) for both goats and sheep. The study covered 117 males and 78 females for goats and 102 males and 93 females for sheep.

This study evidence an estimated prevalence of $C$. tenuicollis of $39 \%(76 / 195)$ in goats and $17.4 \%(34 / 195)$ in sheep. The percentage of infection among the goats was statistically higher than that of the sheep $(\mathrm{p}<0.05)$.

The percentages of $C$. tenuicollis vesicles by location in goats and sheep are described in Table 1 . A total of 153 vesicles were retrieved from 76 positive goats and 66 vesicle $s$ from 34 positive sheep. The most prevalent abdominal locations for $C$. tenuicollis were similar in goats and sheep: the omentum $[41.8 \%(64 / 153)$ and $44 \%$ (29/66), respectively], the mesentery [37.3\% (57/153) and $28.8 \%(19 / 66)$, respectively] and the abomasum [7.2\% $(11 / 153)$ and $9.1 \%(6 / 66)$, respectively]. The average weights of cysticerci presented in the positive animals were $27 \mathrm{~g} \pm 5.8 \mathrm{~g}$ in goats and $41.3 \mathrm{~g} \pm 23 \mathrm{~g}$ in sheep.

The intensity of $C$. tenuicollis, estimated from the number of vesicles presented in the carcass, was wider in goats than in sheep. In goats, $21 \%(16 / 76)$ of positive carcasses presented one vesicle, $59.2 \%(45 / 76)$ presented two vesicles, $17.1 \%(13 / 76)$ three vesicles, and $2.7 \%$ (2/76) four vesicles. In sheep, $29.4 \%$ (10/34) of the positive carcasses presented one vesicle, 47\% (16/34) two vesicles, and $23.6 \%(8 / 34)$, three vesicles. In only one goat the liver presented a major granulomatous lesion that received full condemnation. In the infested viscera of other animals, the 
lesions were caused by the parasite attachment and received partial condemnation.

The characteristics of the herds, farm and management and the presence of the definitive host were analyzed with regard to development of C. tenuicollis in goats and sheep (Table 2). In this study, the parameters tested did not significantly affect $(p<0.05)$ the occurrence of $C$. tenuicollis in goats. In sheep, only the parameter "extensive management" significantly affected the occurrence of cistycercosis ( $\mathrm{p}<0.05)$, which showed an odds ratio of 2.34 (CI 95\%). Sheep raised extensively were twice as likely to present infection.

\section{Discussion}

The prevalence of C. tenuicollis found in this study (39\% in goats and $17.4 \%$ in sheep) is in line with research carried out by Soares et al. (2012) in the back country of Ceará, Brazil. These authors observed high prevalence of $C$. tenuicollis, of $26.2 \%$ in goats and $35.2 \%$ in sheep, and also did not observe any significant differences ( $p>0.05)$ in the quantity of cysticerci, in relation to the sex or age of the animals. In Ethiopia, a study by Wondimu et al. (2011) showed C. tenuicollis was present in $63.9 \%$ of the goats and $56.8 \%$ of the sheep inspected, and that the results presented led to estimated economic losses of US\$ 65,269.89 per year.

In this study, the site of highest prevalence of $C$. tenuicollis was the omentum: $41.8 \%$ of the total vesicles were infecting this location in goats and $44 \%$ of the sheep were infected at that site. The mesentery was the site with the second highest prevalence. Similar results were obtained by Al-Bayati et al. (2012) in Iraq; Wondimu et al. (2011) in Ethiopia; and Payan-Carreira et al. (2008) in Portugal, with highest prevalence in the omentum, followed by the mesentery.

The risk factors found in this study were related to the type of rearing system. Sheep raised extensively were twice as likely to be

Table 1. Number and location of Cysticercus tenuicollis vesicles in goats and sheep in the state of Paraiba, Brazil.

\begin{tabular}{lccccccccc}
\hline & \multicolumn{1}{c}{ Infected locations [n/(\%)] } \\
\cline { 2 - 10 } & Oment. & Mes. & Abom. & Rumen & Liver & Carc. & Bl. & S.I. & L.I. \\
\hline \multirow{2}{*}{ Goats } & 64 & 57 & 11 & 9 & 8 & 1 & 0 & 2 & 1 \\
& $(41.8)$ & $(37.3)$ & $(7.2)$ & $(5.9)$ & $(5.2)$ & $(0.65)$ & - & $(1.3)$ & $(0.65)$ \\
\hline \multirow{2}{*}{ Sheep } & 29 & 19 & 6 & 5 & 3 & 0 & 2 & 2 & 0 \\
& $(44)$ & $(28.8)$ & $(9.1)$ & $(7.6)$ & $(4.5)$ & - & $(3)$ & $(3)$ & - \\
\hline
\end{tabular}

Oment - Omentum; Mes. - Mesentery; Abom. - Abomasum; Carc. - Carcass; Bl. - Bladder; S.I. - Small Intestine; L.I. - Large Intestine.

Table 2. Univariate analysis on the characteristics of the animals and the farms from which they originated, in relation to risk factors for development of Cysticercus tenuicollis in goats and sheep in the state of Paraiba, Brazil.

\begin{tabular}{|c|c|c|c|c|c|c|}
\hline Variable & Number of goats & $\begin{array}{c}\text { C. tenuicollis } \\
\text { goats (\%) }\end{array}$ & $P$ & Number of sheep & $\begin{array}{l}\text { C. tenuicollis } \\
\text { sheep (\%) }\end{array}$ & $P$ \\
\hline Sex & 97 & $40(41.2)$ & 0.619 & 97 & $14(14.4)$ & 0.362 \\
\hline $\begin{array}{l}\text { Male } \\
\text { Female }\end{array}$ & 98 & $36(36.7)$ & & 98 & $20(20.4)$ & \\
\hline \multicolumn{7}{|l|}{ Age } \\
\hline$<1$ year & 111 & $37(33.3)$ & 0.119 & 116 & $22(19.0)$ & 0.753 \\
\hline$>1$ year $<2$ years & 70 & $34(48.6)$ & & 63 & $10(15.9)$ & \\
\hline$>2$ years & 14 & $5(35.7)$ & & 16 & $2(12.5)$ & \\
\hline \multicolumn{7}{|l|}{ Management } \\
\hline Extensive & 30 & $16(53.3)$ & & 26 & $9(34.6)^{*}$ & 0.023 \\
\hline Semi-intensive & 165 & $60(36.4)$ & 0.121 & 169 & $25(14.8)$ & \\
\hline \multicolumn{7}{|l|}{ Presence of dogs } \\
\hline No & 56 & $23(41.1)$ & & 56 & $8(14.3)$ & \\
\hline Yes & 139 & $53(38.1)$ & 0.825 & 139 & $26(18.7)$ & 0.598 \\
\hline \multicolumn{7}{|l|}{ Dewormed animals } \\
\hline No & 61 & $25(41.0)$ & & 57 & $10(17.5)$ & \\
\hline Yes & 134 & $51(38.1)$ & 0.818 & 138 & $24(17.4)$ & 1.000 \\
\hline \multicolumn{7}{|l|}{ Farm area } \\
\hline Up to 10 ha & 60 & $23(38.8)$ & 0.455 & 60 & $10(16.7)$ & 0.970 \\
\hline 11 to $20 \mathrm{ha}$ & 26 & $13(50.0)$ & & 24 & $4(16.7)$ & \\
\hline Over 20 ha & 109 & $40(40.7)$ & & 111 & $20(18.0)$ & \\
\hline \multicolumn{7}{|l|}{ Size of the herd } \\
\hline 30 animals & 12 & $7(58.3)$ & 0.262 & 14 & $3(21.4)$ & \\
\hline $31-100$ & 107 & $43(40.2)$ & & 105 & $17(16.2)$ & - \\
\hline Over 100 & 76 & $26(34.2)$ & & 76 & $14(18.4)$ & \\
\hline
\end{tabular}

*The variable of sheep management significant at $\mathrm{p}<0.05$. 
infected by $C$. tenuicollis. The high rates of infection among animals that are reared extensively probably result from the longer periods of time for which these animals are exposed to environments in which infected dogs (definitive hosts) are present.

Most of these small-ruminant farms had dogs. It is known that the best way to prevent $C$. tenuicollis is by deworming definitive hosts. However, none of the owners said they had conducted deworming among their dogs and all of these dogs had free access to the pastures, favoring the persistence of the livestock infection. In addition, stray dogs can circulate for several properties, a source of environmental contamination with $T$. hydatigena eggs, even in properties without dogs. In the region, the problem is aggravated by the habit of feeding dogs with raw viscera, especially in properties that perform illegal slaughter. In addition, dogs may have access to the carcass of dead animals on properties.

\section{Conclusion}

It was concluded that there is high prevalence of $C$. tenuicollis in small ruminants in the state of Paraiba and that this parasite is more prevalent in goats than in sheep. Extensive rearing is considered to be a risk factor for development of this parasite in sheep.

\section{References}

Al-Bayati SM, Azeez OH, Abdullah AM. Biochemical and Histological study of Cysticercus tenuicollis of sheep in Duhok Province. Braz J Vet Res 2012; 11(1): 52-57.

Amarante AFT. Nematódeos gastrintestinais em ovinos. In: Cavalcante ACR, Vieira LS, Chagas ACS, Molento MB. Doenças parasitárias de caprinos e ovinos: epidemiologia e controle. 1st ed. Brasília: EMBRAPA; 2009. p. 17-62.

Andrade GM. Controladoria em agronegócios: um estudo sobre a caprinocultura de leite nas microrregióes dos Cariris do Estado da Paraíba [Dissertaçáo]. João Pessoa: Universidade de Brasília; 2007.

Ayres M, Ayres JRM, Ayres DL, Santos AS. BioEstat 3.0: Aplicaçôes estatísticas nas áreas de ciências biológicas. Belém: Sociedade Civil Mamirauá; 2003.

Christodoulopoulos G, Theodoropoulos G, Petrakos G. Epidemiological survey of cestode-larva disease in Greek sheep flocks. Vet Parasitol 2008;
153(3-4): 368-373. PMid:18346853. http://dx.doi.org/10.1016/j. vetpar.2008.02.002.

Instituto Brasileiro de Geografia Estatística - IBGE. Sistema IBGE de Recuperação Automática - SIDRA [online]. Rio de Janeiro: IBGE; 2006 [cited 2014 Nov 15]. Available from: http://www2.sidra.ibge.gov.br/ bda/pecua/default.asp? $z=t \& o=24 \& \mathrm{i}=\mathrm{P}$

Instituto Brasileiro de Geografia Estatística - IBGE. Sistema IBGE de Recuperação Automática - SIDRA [online]. Rio de Janeiro: IBGE; 2015 [cited 2016 Dec 12]. Available from: http://www2.sidra.ibge.gov.br/ bda/pecua/default.asp?t=2\&z=t\&o=24\&u1 $=1 \& u 3=1 \& u 4=1 \& u 5=1 \&$ $\mathrm{u} 6=1 \& \mathrm{u} 7=1 \& \mathrm{u} 2=22$

Kouam MK, Diakou A, Kantzoura V, Feidas H, Theodoropoulou $\mathrm{H}$, Theodoropoulos G. An analysis of seroprevalence and risk factors for parasitic infection of economic importance in small ruminants in Greece. Vet J 2014; 202(1): 146-152. PMid:25155306. http://dx.doi. org/10.1016/j.tvjl.2014.07.011.

Oryan A, Goorgipour S, Moazeni M, Shirian S. Abattoir prevalence, organ distribution, public health and economic importance of major metacestodes in sheep, goats and cattle in Fars, southern Iran. Trop Biomed 2012; 29(3): 349-359. PMid:23018497.

Payan-Carreira R, Silva F, Rodrigues M, Anjos PM. Cysticercus tenuicollis vesicle in fetal structures: report of a case. Reprod Domest Anim 2008; 43(6): 764-766. PMid:18564316. http://dx.doi.org/10.1111/j.14390531.2007.01014.x.

Popova TP, Kanchev K. Microflora of internal organs and muscles of lambs and pigs in spontaneous infection with Cysticercus tenuicollis. Bulg J Agric Sci 2013; 19(2): 325-330.

Scala A, Urrai G, Varcasia A, Nicolussi P, Mulas M, Goddi L, et al. Acute visceral cysticercosis by Taenia hydatigena in lambs and treatment with praziquantel. J Helminthol 2016; 90(1): 113-116. PMid:25120032. http://dx.doi.org/10.1017/S0022149X14000601.

Soares LB, Miquelotti DR, Grisi L, Serra-Freire NM. Indicadores de parasitismo por Cysticercus tenuicollis em pequenos ruminantes no sertão central do Ceará, Brasil. Rev Bras Med Vet 2012; 34(2): 106-110.

Thrusfield M. Veterinary epidemiology. 3rd ed. Oxford: Blackwell Science; 2007.

Wondimu A, Abera D, Hailu Y. A study on the prevalence, distribution and economic importance of Cysticercus tenuicollis in visceral organs of small ruminants slaughtered at an abattoir in Ethiopia. J Vet Med Anim Health 2011; 3(5): 67-74. 